\title{
Nutrient Composition of Atriplex Leaves Grown in Saudi Arabia
}

\author{
JEHANGIR K. KHALIL, WAJIH N. SA WAYA, AND SYED Z. HYDER
}

\begin{abstract}
Leaves of 6 Atriplex species (saltbush) grown in Saudi Arabia were studied for their nutritive characteristics. Crude protein contents varied between $16.7-25.2 \%$, crude fat between $1.0-1.6 \%$, crude fiber between $7.8-10.4 \%$, and ash between $18.5-27.2 \%$, on a dry matter basis. $A$. undulata had the lowest and $A$. nummularia had the highest protein and fiber contents. Ash content was lowest in $A$. canescens and highest in $A$. undulata. The level of $\mathrm{Na}$ was extremely low $(0.21 \%)$ in $A$. canescens compared to that in the other species $(2.38-5.57 \%)$. The level of $\mathrm{K}(6.06 \%)$ was highest in A. canescens compared to $2.48-3.54 \%$ in other species. Ca content was significantly higher in $A$. vesicaria $(2.48 \%)$ than that in the remaining species (1.12-1.50\%). Variations in the levels of $\mathrm{P}, \mathrm{Mg}$, $\mathrm{Fe}, \mathrm{Zn}, \mathrm{Cu}$, and $\mathrm{Mn}$ were only minor. Sulphur amino acids (methionine + cystine) were the most deficient essential amino acids in all species (chemical score $=\mathbf{4 5}$ - 61) while lysine contents were 75 $>100 \%$ of the FAO/WHO (1973) reference protein. Predicted digestible dry matter ranged between 74.5 - 78.8\% and digestible energy (M Cals/Kg) between 3.215 - 3.399. These data suggest that Atriplex leaves as a range forage for livestock would have good nutritive value.
\end{abstract}

Atriplex species commonly known as saltbush are strong candidates for plant establishments in saline areas and for increasing productivity in arid or semiarid regions of the world because of their salt tolerance and high productivity (Kleinkopf et al. 1975). Hence these plants have been grown as a forage shrub for many years in marginal agricultural lands in South Africa, Australia, USA and the Middle East (Goodin and McKell 1970). In the Kingdom of Saudi Arabia, where prolonged drought and excessive salinity are common, several species of Atriplex were grown successfully on marginal agricultural lands (Hyder 1981). Atriplex species are reported to show considerable variation in their chemical composition (Smit and Jacobs 1978) and differ considerably in their responses to sodium salts (Goodin and McKell 1970). Considerable information on the chemical composition and nutritional characteristics of the Atriplex species is available in the literature (Beadle et al. 1957, Goodin and McKell 1970, Chatterton et al. 1971, NAS 1971, Welch 1978, Smit and Jacobs 1978, Davis 1981, Welch and Monsen 1981, McArthur et al. 1984). However, such information on Atriplex species grown in the Kingdom of Saudi Arabia was lacking except for the protein and ash contents of some species reported by Hyder (1981). The present investigation was undertaken in an attempt to characterize the forage value of the leaves of six Atriplex species grown under the environmental conditions of Saudi Arabia. Atriplex leaves alone were included in this study because goats, which along with sheep and camels are the major grazing animals, show unique preferences for shrub and tree leaves (NRC 1981). Moreover, compositional information on the leaves alone was scarce for most of the Atriplex species under study especially those grown in Saudi Arabia.

\section{Materials and Methods}

\section{Preparation of Samples}

Mature dry leaves were collected from 6 Atriplex species, $A$. nummularia Lindl., A. rhagodioides F. Muell., A. vesicaria Heward., A. canescens (Pursh) Nutt., A. lentiformis (Torr) S. Wats

\footnotetext{
Authors are with the Regional Agriculture and Water Research Center, Ministry of Agriculture and Water, P.O. Box 17285, Riyadh 11484, Saudi Arabia.

Manuscript accepted 11 June 1985.
}

and $A$. undulata (moq.) Dietr. The plants were exotic introductions from Australia and U.S.A. The seeds of $A$. nummularia, $A$. rhagodioides and $A$. vesicaria were supplied by C.V. Malcolm, Research Officer, Department of Agriculture, Perth, Western Australia. Seeds of the other Atriplex species were obtained from Dr. L.R. Green, range scientist, Forest Fire Laboratory, Riverside, California, U.S.A. Plants were grown at the Regional Agriculture and Water Research Center, Riyadh (Hyder 1981). Seeds were sown in the greenhouse in November 1977 in earthern pots $(30 \mathrm{~cm}$ in diameter and $12 \mathrm{~cm}$ deep) with 1:1 mixture of sand and peat. Pots were watered regularly. All species germinated within 1 month. When large enough, individual seedlings were transferred to separate containers ( $12 \mathrm{~cm}$ diameter and $6 \mathrm{~cm}$ deep) having the same mixture of sand and peat. After 3 weeks in the greenhouse, the seedlings $(12-16 \mathrm{~cm}$ in height) were transferred to the field plots in January 1978. The transplants were placed $1.75 \mathrm{~m}$ apart in rows which were $2 \mathrm{~m}$ apart and irrigated immediately. The plants were harvested in April 1980. All the plants had completed phenological stages of flowering, fruit, and seed production. Leaves were collected from 10-15 plants of each species, air dried and ground in a micro mill (Technilab Instruments, Pequannock, N.J., Model \#502) to pass $1 \mathrm{~mm}$-sieve, and stored in a freezer $\left(-5^{\circ} \mathrm{C}\right)$ until analysed.

\section{Chemical Composition}

Analysis for moisture, crude protein $(\mathrm{N} \times 6.25)$, crude fat, crude fiber, ash and nitrogen-free extract (NFE) (by difference) were done by methods of AOAC (1980). Acid detergent fiber (ADF) values were determined following the procedure by Goering and Van Soest (1970). For mineral analysis, the dry ash was dissolved in $20 \% \mathrm{HCl}$ and necessary dilutions made with deionized water. $\mathrm{Na}$ and $\mathrm{K}$ were estimated with a flame photometer (Beckman, Klina flame). $\mathrm{Ca}, \mathrm{Mg}, \mathrm{Fe}, \mathrm{Zn}, \mathrm{Cu}$ and $\mathrm{Mn}$ were determined with an atomic absorption spectrophotometer (Perkin-Elmer, Model 603). $P$ was determined by the procedure of Watanabe and Olsen (1965). For $\mathrm{Ca}$ and $\mathrm{Mg}$, the final diluted solutions contained $1 \%$ lanthanum to reduce interferences.

For amino acid analysis, duplicate samples containing $5 \mathrm{mg}$ protein were hydrolysed with $6 \mathrm{~N} \mathrm{HCl}$ for 24 hours at $110^{\circ} \mathrm{C}$. Cystine was determined as Cysteic acid (Moore 1963) and tryptophan by the alkaline hydrolysis procedure of Hugli and Moore (1972). All the hydrolysates were analysed with an automatic amino acid analyser (Beckman, $119 \mathrm{CL}$ ). The chemical scores were determined by dividing the contents of the essential amino acids in the Atriplex leaf proteins by the contents of the same amino acid in the FAO/WHO reference protein (FAO/WHO 1973).

\section{Nutritional Characteristics}

Digestible dry matter (DDM), digestible energy (DE), and metabolizable energy (ME) were calculated from the chemical data. DDM was calculated from the ADF values and DE from the DDM values using the following equations reported by Fonnesbeck et al. (1984) for alfalfa hay:

$$
\begin{gathered}
\text { DDM } \%=88.9-0.779(\mathrm{ADF}) \\
\mathrm{DE} \%=0.628+0.984(\mathrm{DDM} \%) \\
\mathrm{DE}(\mathrm{M} \text { cals } / \mathrm{kg})=0.027+0.0428(\mathrm{DDM} \%)
\end{gathered}
$$

For the calculation of the $\mathrm{ME}$, the following equation was used (Gonzalez and Everitt 1982):

$\mathrm{ME}(\mathrm{M}$ cals $/ \mathrm{kg})=\mathrm{DE}(\mathrm{M}$ cals $/ \mathrm{kg}) \times 0.8210$ 


\section{Results and Discussion}

\section{Proximate Composition}

Proximate analysis data are reported in Table I. Considerable variations in the crude protein, ash, and carbohydrate contents were observed among the leaves of the 6 Atriplex species. The percentage values of fat and fiber showed relatively small variations. The protein content varied from $16.7 \%$ in $A$. undulata to $25.2 \%$ in $A$. nummularia; mean was $19.4 \%$ for the 6 species. Smit and Jacobs (1978) also reported considerable variations in the

Table 1. Proximate composition 1 of Atriplex leaves.

\begin{tabular}{lccccc}
\hline \hline Atriplex & $\begin{array}{c}\text { Protein } \\
(\mathrm{N} \times 6.25) \%\end{array}$ & $\begin{array}{c}\text { Fat } \\
\text { species }\end{array}$ & $\begin{array}{c}\text { Fiber } \\
\%\end{array}$ & $\begin{array}{c}\text { Ash } \\
\%\end{array}$ & $\begin{array}{c}\text { Nitrogen- } \\
\text { free } \\
\text { extract }\end{array}$ \\
\hline A. nummularia & 25.2 & 1.1 & 10.4 & 24.3 & 39.0 \\
A. canescens & 17.4 & 1.6 & 9.0 & 18.5 & 53.5 \\
A. vesicaria & 17.8 & 1.6 & 8.3 & 34.1 & 38.2 \\
A. rhagodioides & 17.2 & 1.0 & 10.2 & 22.8 & 48.8 \\
A. lentiformis & 21.9 & 1.1 & 8.0 & 22.0 & 47.0 \\
A. undulata & 16.7 & 1.3 & 7.8 & 27.2 & 47.0 \\
Mean & 19.4 & 1.3 & 9.0 & 24.8 & 45.6 \\
\hline
\end{tabular}

'Dry weight basis. protein content among Atriplex species, as well as seasonal variations within species. Welch and Monsen (1981) reported winter crude protein levels of 6-14\% of dry weight in 43 accessions of fourwing saltbush ( $A$. canescens) and indicated that genetic variation plays an important role in determining the level of protein in this Atriplex species. McArthur et al. (1984) reported seasonal variations in the protein content of ' $R$ incon' fourwing saltbush ( $A$. canescens) ranging from $17.9 \%$ in November to $26.5 \%$ in June in the leaves with intermediate values for other seasons. Goodin and McKell (1970) indicated a decrease of approximately $2 \%$ in the protein content of $A$. lentiformis and $3 \%$ in $A$. polycarpa between the first and second harvest separated by 1 -month intervals. The National Research Council (NRC 1976) recommended 9.2\% and $5.2 \%$ crude protein for lactating and dry beef cows, respectively. The protein content of the dry leaves of the 6 Atriplex species exceeded these requirements. Moreover, the data suggest that these leaves could be used as a protein supplement with other forage crops such as dormant grasses which usually are deficient in this nutrient (Gonzalez and Everitt 1982). The crude protein content of the leaves of Atriplex species was also higher than the requirements for sheep (8.9-16\%, NRC 1975). Similarly, it exceeded the protein needs suggested for maintenance, live weight gain of goats, and for pregnant and lactating does (NRC 1981).

The percentage of fat varied between $1.0-1.6 \%$. The fat values

Table 2. Mineral element content' ${ }^{1}$ of Atriplex leaves.

\begin{tabular}{|c|c|c|c|c|c|c|c|c|c|}
\hline \multirow[b]{2}{*}{ Atriplex species } & $\mathrm{Na}$ & $\mathbf{K}$ & $\mathrm{Ca}$ & $\mathbf{P}$ & $\mathbf{M g}$ & $\mathrm{Fe}$ & $\mathrm{Zn}$ & $\mathrm{Cu}$ & $\mathrm{Mn}$ \\
\hline & \multicolumn{5}{|c|}{$\%$} & \multicolumn{4}{|c|}{$\mu g / g$} \\
\hline A. nummularia & 4.85 & 2.49 & 1.44 & 0.24 & 0.76 & 420 & 54 & 24 & 74 \\
\hline A. canescens & 0.21 & 6.06 & 1.31 & 0.19 & 0.72 & 370 & 59 & 20 & 84 \\
\hline A. vesicaria & 4.95 & 2.86 & 2.48 & 0.18 & 0.84 & 350 & 58 & 23 & 78 \\
\hline A. rhagodioides & 2.38 & 2.48 & 1.50 & 0.22 & 0.59 & 335 & 66 & 25 & 82 \\
\hline A. lentiformis & 4.91 & 2.76 & 1.12 & 0.28 & 0.79 & 250 & 59 & 26 & 75 \\
\hline A. undulata & 5.57 & 3.54 & 1.45 & 0.24 & 0.66 & 485 & 70 & 26 & 89 \\
\hline
\end{tabular}

IDry weight basis.

Table 3. Amino acid composition of Atriplex leaves (g amino acid/100 $\mathrm{g}$ protein).

\begin{tabular}{|c|c|c|c|c|c|c|c|}
\hline \multirow[b]{2}{*}{ Amino acid } & \multicolumn{7}{|c|}{ Atriplex species } \\
\hline & A. nummularia & A. canescens & A. vesicaria & A. rhagodioides & A. lentiformis & A. undulata & $\begin{array}{c}\text { FAO/ WHO } \\
(1973)\end{array}$ \\
\hline Aspartic acid & 5.96 & 4.83 & 6.52 & 5.68 & 5.01 & 4.81 & - \\
\hline Threonine & 2.90 & 2.52 & 3.27 & 2.90 & 2.57 & 2.50 & 4.0 \\
\hline Serine & 3.12 & 2.56 & 3.61 & 3.05 & 2.62 & 2.85 & - \\
\hline Glutamic acid & 6.89 & 5.62 & 7.28 & 6.69 & 5.54 & 5.33 & - \\
\hline Proline & 3.22 & 2.62 & 2.47 & 3.68 & 2.13 & 2.08 & - \\
\hline Glycine & 3.54 & 2.96 & 3.75 & 3.39 & 2.86 & 3.09 & - \\
\hline Alanine & 3.79 & 3.03 & 3.99 & 3.68 & 3.26 & 3.25 & - \\
\hline Valine & 3.65 & 2.84 & 4.04 & 3.39 & 2.83 & 3.16 & 5.0 \\
\hline Methionine (M) & 0.87 & 0.91 & 0.94 & 0.85 & 0.80 & 0.80 & - \\
\hline Cystine (C) & 0.69 & 0.74 & 0.85 & 1.18 & 0.80 & 1.32 & - \\
\hline $\mathbf{M}+\mathbf{C}$ & $1.56^{\mathrm{I}}$ & $1.65^{1}$ & 1.791 & $2.03^{1}$ & $1.60^{1}$ & $2.12^{\prime}$ & 3.5 \\
\hline Isoleucine & 3.27 & 2.42 & 3.34 & 2.87 & 2.30 & 2.38 & 4.0 \\
\hline Leucine & 5.04 & 4.00 & 5.41 & 4.97 & 4.14 & 4.02 & 7.0 \\
\hline Tyrosine $(T)$ & 1.99 & 1.58 & 2.15 & 1.93 & 1.59 & 1.67 & - \\
\hline Phenylalanine (P) & 3.20 & 2.60 & 2.55 & 3.15 & 2.53 & 2.55 & - \\
\hline $\mathbf{T}+\mathbf{P}$ & 5.19 & 4.18 & 4.70 & 5.08 & 4.12 & 4.22 & 6.0 \\
\hline Lysine & 5.44 & 4.22 & 5.71 & 5.04 & 4.08 & 4.09 & 5.5 \\
\hline Histidine & 1.53 & 1.15 & 1.53 & 1.12 & 0.91 & 0.93 & - \\
\hline Arginine & 5.30 & 2.50 & 3.57 & 2.79 & 2.63 & 2.27 & - \\
\hline Tryptophan & 0.62 & 0.60 & 0.77 & 0.93 & 0.79 & 0.74 & 1.0 \\
\hline $\mathbf{N H}_{3}$ & 2.53 & 2.86 & 2.70 & 1.14 & 1.22 & 1.37 & - \\
\hline Chemical score & 45 & 47 & 51 & 58 & 46 & 61 & 100 \\
\hline
\end{tabular}

'First limiting essential amino acid. 
are slightly lower than those of NAS (1971) for Atriplex leaves (1.9-2.7\%) and 2.5-3.5\% reported by Chatterton et al. (1971) in the leaves of $A$. polycarpa. The ash contents varied between $18.5 \%$ in $A$. canescens to $34.1 \%$ in $A$. vesicaria. These values are in agreement with those reported by NAS (1971). Chatterton et al. (1971) reported considerable variation in the total ash content of $A$. polycarpa leaves (15-20\%) with the highest value during late summer.

The crude fiber content was highest in A. nummularia (10.4\%) and lowest in $A$. undulata (7.8\%). These values are comparable to those reported for $A$. polycarpa leaves by Chatterton et al. (1971). The fiber as well as ash content showed large seasonal variations in Atriplex species (Chatterton et al. 1971, Davis 1979). However, these seasonal variations in fiber content were lowest in the leaves compared to the stems or whole plant (Chatterton et al. 1971). NFE varied from $38.2 \%$ in $A$. vesicaria to $53.5 \%$ in $A$. canescens. These values are close to $40-45 \%$ reported by Chatterton et al. (1971) in the leaves of $A$. polycarpa and compare favorably with the values of NAS (1971).

\section{Mineral Contents}

Data on the mineral element contents are shown in Table 2. All the mineral elements showed a wide range of variation except $\mathrm{Cu}$, which differed over a narrow range. The concentration of $\mathrm{Na}$ was lowest in $A$. canescens $(0.21 \%)$ and highest in $A$. undulata $(5.57 \%)$. Other investigators have also reported much lower $\mathrm{Na}$ levels in $A$. canescens compared to the $\mathrm{Na}$ levels in the leaves of other Atriplex species (Wallace et al. 1973, Smit and Jacobs 1978). Richardson (1982) showed that distinct biotypes of $A$. canescens exist with regard to $\mathrm{Na}$ accumulation. $\mathrm{Na}$ levels in all the species were well above the $0.06 \%$ level considered adequate for beef cattle (NRC, 1976). It was also much higher (except $A$. canescens) than $0.5 \%$ level considered adequate for goats (NRC 1981) and $0.04-0.1 \%$ of diet dry matter considered adequate for sheep (NRC 1975). Goats in particular can consume $\mathrm{Na}$ in excess of their requirements with no apparent ill effects (NRC 1981).

In contrast to $\mathrm{Na}$, the concentration of $\mathrm{K}$ was maximum in $A$. canescens, and relatively much lower in other species. High levels of $\mathrm{Na}$ in the leaves tend to depress the $\mathrm{K}$ levels (Wallace et al. 1982). Richardson (1982) reported large ecotype differences in the leaves of $\boldsymbol{A}$. canescens for $\mathbf{K}$ accumulation. $\mathrm{K}$ concentrations in leaves were high when $\mathrm{Na}$ concentrations were low. The $\mathrm{K}$ levels in all the species were well above the (0.6-0.8\%) minimum requirement range for cattle (NRC 1976) and $0.5 \%-0.8 \%$ range for goats and sheep (NRC 1975, 1981).

The $\mathrm{Ca}$ content varied from 1.12 to $2.48 \%$, with $A$. vesicaria containing significantly higher amounts of Ca compared to the other species. All species had Ca levels that exceeded the requirements $(0.18 \%-0.44 \%)$ for beef cattle (NRC 1976), $0.138 \%$ for goats (NRC 1981), and $0.21-0.52 \%$ for sheep (NRC 1981). The levels of $P$ $(0.18-0.28 \%)$ were satisfactory in comparison to $0.18 \%$ considered adequate for dry cows (NRC 1976) but were below the $0.39 \%$ level considered adequate for lactating cows (NRC 1976). A similar situation existed for sheep with requirements of $0.16-0.37 \%$ (NRC 1975). This was also true for goats (NRC 1981). The concentration of $\mathrm{Mg}$ was lowest in $A$. rhagodioides $(0.59 \%)$ and highest $(0.84 \%)$ in $A$. vesicaria. The range of $\mathbf{M g}$ was well above the $\mathrm{Mg}$ requirements (0.04-0.18\%) of beef cattle (NRC 1976), sheep and goats (0.04-0.08\%) (NRC 1975, 1981).

Among the micro-elements, the level of $\mathrm{Fe}$ ranged between $250-485 \mu \mathrm{g} / \mathrm{g}$ dry leaves, which is higher than the values reported for some Atriplex species (Wallace et al. 1982). Although minimal requirement for $\mathrm{Fe}$ has not been established, $80-100 \mu \mathrm{g} / \mathrm{g}$ feed is considered ample for beef cattle (NRC 1976) and 30-50 $\mu \mathrm{g} / \mathrm{g}$ dry matter for sheep and goats (NRC 1975, 1981). Atriplex leaves are, therefore, adequate in $\mathrm{Fe}$ for beef cattle, sheep, and goats. In contrast to $\mathrm{Fe}$, the contents of $\mathrm{Zn}$ and $\mathrm{Cu}$ tended to be lower than the values of Wallace et al. (1982). Only Mn levels were relatively comparable with the data of above authors. The level of $\mathrm{Zn}$ in
Atriplex leaves was well above the suggested requirement level (20-30 $\mu \mathrm{g} / \mathrm{g}$ of diet dry matter) for beef cattle (NRC 1976), $10 \mu \mathrm{g} / \mathrm{g}$ for goats (NRC 1981) and 35-50 $\mu \mathrm{g} / \mathrm{g}$ for sheep (NRC 1975). Cu content was also well above the $4 \mu \mathrm{g} / \mathrm{g}$ of diet dry matter suggested as a requirement for beef cattle (NRC 1976) and $5 \mu \mathrm{g} / \mathrm{g}$ feed suggested for sheep (NRC 1975). Similarly, the Mn level exceeded the $1-10 \mu \mathrm{g} / \mathrm{g}$ requirement for beef cattle (NRC 1976) and 20-40 $\mu \mathrm{g} / \mathrm{g}$ for sheep (NRC 1975).

\section{Amino Acid Composition}

The amino acid contents of Atriplex leaves have been studied as a possible source of plant protein (Silva and Pereira 1976) and for providing information for taxonomic studies (Cozic-Trichet and Goas 1969). In general, there is very limited information on the amino acid profile of Atriplex leaf protein. Because of these reasons, the amino acid composition of the 6 Atriplex leaf proteins was studied and the results are shown in Table 3 . Considerable variations in the concentrations of some amino acids were observed. Total sulphur amino acids (methionine + cystine) were the first limiting essential amino acids in all the Atriplex species. The chemical score (FAO/WHO 1973) ranged between 45-61, with $A$. undulata showing the highest chemical score. Lysine, which is the most deficient essential amino acid in cereal proteins, was present in levels higher than those of cereal protein. However, it was slightly lower than the FAO/WHO reference protein (1973), except $A$. vesicaria protein, which contained slightly higher lysine than that in FAO/WHO (1973) pattern. In general, the lysine contents were between $75->100 \%$ of the reference protein. These results indicated that Atriplex leaf protein has a good amino acid profile and these proteins could supplement those of cereal proteins. In general, these findings are similar to those of Silva and Pereira (1976).

\section{ADF, DDM, DE and ME}

The ADF values (Table 4) ranged from a minimum value of $13.0 \%$ in $A$. undulata to a maximum value of $18.5 \%$ in $A$. lentiformis. The DDM values ranged between $74.5 \%-78.8 \%$. Data on the

Table 4. Acid Detergent Fiber (ADF), Digestible Dry Matter (DDM), Digestible Energy (DE) and Metabolizable Energy (ME) of Atriplex leaves (dry weight basis).

\begin{tabular}{|c|c|c|c|c|c|}
\hline \multirow[b]{2}{*}{ Atriplex species } & \multirow{2}{*}{$\underset{\%}{\mathbf{A D F}^{1}}$} & \multirow{2}{*}{$\begin{array}{c}\mathrm{DDM}^{2} \\
\%\end{array}$} & \multicolumn{2}{|r|}{$\mathrm{DE}^{2}$} & \multirow{2}{*}{$\begin{array}{c}\mathrm{ME}^{3} \\
(\mathrm{M} \text { cals } / \mathrm{Kg})\end{array}$} \\
\hline & & & $\%$ & ( $\mathrm{M}$ cals $\left./ \mathrm{K}_{\mathrm{g}}\right)$ & \\
\hline A. nummularia & 15.5 & 76.8 & 74.9 & 3.314 & 2.717 \\
\hline A. canescens & 14.1 & 77.9 & 76.0 & 3.361 & 2.756 \\
\hline A. vesicaria & 13.8 & 78.2 & 76.3 & 3.373 & 2.765 \\
\hline A. rhagodioides & 15.2 & 77.1 & 75.2 & 3.326 & 2.727 \\
\hline A. lentiformis & 18.5 & 74.5 & 72.6 & 3.215 & 2.636 \\
\hline A. undulata & 13.0 & 78.8 & 76.9 & 3.399 & 2.787 \\
\hline
\end{tabular}

IADF determined following the procedure of Goering and Van Soest (1970). ${ }^{2}$ Calculated by the prediction equation of Fonnesbeck et al. (1984).

3Calculated by the equation, ME $(\mathrm{M} \mathrm{cal} / \mathrm{Kg})=\mathrm{DE}(\mathrm{M}$ cals $/ \mathrm{Kg}) \times 0.82$ (Gonazalez and Everitt 1982).

DDM values for Atriplex leaves alone is scarcely reported in the literature. However, values for total digestible nutrients (TDN \%) in Atriplex leaves are reported to be $40.2 \%$ and $45.5 \%$ for cattle and sheep, respectively (NAS 1971). The DDM values were comparable to in-vitro dry matter digestibility values $(66.8 \%-77.0 \%)$ for moth bean plant (Vigna aconitifolia), a forage crop of the arid and semiarid areas (Arora et al. 1975). The DE (M cals/ $\mathrm{Kg}$ ) levels of all the species were higher than 2.20 and $2.50 \mathrm{M}$ cals $/ \mathrm{Kg}$ required to meet the needs of dry and lactating cows, respectively (NRC 1976) and approximate to the needs of sheep and goats (NRC 1975, 1981). The DE values, as expected, were generally higher than most other forage crops but comparable to that of prickly pear cactus (Gonzalez and Everitt 1982). The ME values were also higher than values, $1.82-1.86 \mathrm{ME} / \mathrm{kg}$ dry matter, for the whole browse (Atriplex species) (Gohl 1981). Although the methods used to estimate 
energy value are based on an alfalfa equation, these data suggest that Atriplex leaves have good digestibility and energy values.

In conclusion, leaves of Atriplex species have a good nutritional potential as a feed for livestock. However, feeding trials are needed to determine their palatability and, if necessary, to ascertain means of increasing their palatability.

\section{Literature Cited}

AOAC. 1980. Official Methods of Analysis. 13th ed. Association of Official Analytical Chemists, Washington, D.C.

Arora, S.K., B. Das, R.S Paroda, and Y.P. Luthra. 1975. Structural carbohydrates influencing the invitro digestibility of moth (Phaseolus aconitifolius, Jacq.). Forage Res. I:107-113.

Beadle, N.C.W., R.D.B. Whalley, and J.B. Gibson. 1957. Studies in halophytes. II. Analytic data on the mineral constituents of three species of Atriplex and their accompanying soils in Australia. Ecology. 38:340344.

Chatterton, N.J., J.R. Goodin, C.M. McKell, R.V.Parker, and J.M Rible. 1971. Monthly variation in the chemical composition of desert-saltbush. J. Range Manage. 24:37-40.

Cozic-Trichet, J., and M. Goas. 1969. Taxonomic study of some Atriplex amino acid and free amines. C.R. Acad. Sci. (Paris). 268:1034-1037.

Davis, A.M. 1979. Forage quality of prostrate Kochia compared with three browse species. Agronomy J. 71:822-824.

Davis, A.M. 1981. The oxalate, tannin, crude fiber and crude protein composition of young plants of some Atriplex species. J. Range Manage. 34:329-331.

FAO/WHO. (1973). Energy and protein requirements. FAO nutritional meetings report series No. 52; WHO technical report series No. 522. Food and Agriculture Organization, Rome.

Fonnesbeck, P.V., D.H. Clark, W.N. Garrett, and C.F. Speth. 1984. Predicting energy utilization from alfalfa hay from the Western Region. Proc. Amer. Soc. Anim. Sci. (Western Section). 35:305-308.

Goering, H.K., and P.J. Van Soest. 1970. Forage fiber analysis. Apparatus, reagents, procedures and some applications. Handbook No. 379, U.S. Dep. of Agr., Washington, D.C.

Gohl, B. 1981. Tropical feeds. FAO Animal Production and Health Series No. 12, Food and Agriculture Organization of the United Nations, Rome.

Gonzalez, C.L., and J.H. Everitt. 1982. Nutrient contents of major food plants eaten by cattle in the south Texas plains. J. Range Manage. 35:733-736.

Goodin, J.R., and C.M. McKell. 1970. Atriplex spp. as a potential forage crop in marginal agricultural areas. Proc. XI International Grassland Congress. Univ. Queensland Press, Brisbane.
Hugll, T.E., and S. Moore. 1972. Determination of the tryptophan content of proteins by ion-exchange chromatography of alkaline hydrolysates. $J$. Biol. Chem. 247:2828-2834.

Hyder, S.Z. 1981. Preliminary observations on the performance of some exotic species of Atriplex in Saudi Arabia. J. Range Manage. 34:208-210.

Kleinkopf, G.E., A. Wallace, and J.W. Cha. 1975. Sodium relations in desert-plants. 4. Some physiological responses of Atriplex confertifolia to different levels of Sodium chloride. Soil Sci. 120:45-48.

McArthur, E.D., S.E. Stranathan, and G.L. Nollar. 1981. 'Rincon' fourwing saltbush - proven for better forage and reclamation. Rangelands. 6:62-64.

Moore, S. 1963. On the determination of cystine as cysteic acid. J. Biol. Chem. 238:235-237.

NAS. 1971. Atlas of nutritional data on United States and Canadian foods. National Academy of Sciences, Washington, D.C.

NRC. 1975. Nutrient requirements of domestic animals. No. 5. Nutrient requirements of sheep. 5th revised ed. National Research Council, National Academy of Sciences, Washington, D.C.

NRC. 1976. Nutrient requirements of domestic animals. No. 4. Nutrient requirements of beef cattle. Sth revised ed. National Research Council, Washington, D.C.

NRC. 1981. Nutrient requirements of domestic animals. No. 15. Nutrient requirements of goats. National Research Council, National Academy Press, Washington, D.C.

Richardson, S.G. 1982. High and low sodium biotypes of fourwing saltbush: Their responses to sodium and potassium in retorted oil shale. J. Range Manage. 35:795-797.

Silva, S.E., and C.C. Pereira. 1976. Isolation and composition of leaf proteins of Atriplex nummularia and Atriplex repanda. Ciencia Investigacion Agraria. 3:169-174.

Smit, C.J., and G.A. Jacobs. 1978. Chemical composition of four Atriplex species. Agroanimalia. 10:1-5.

Wallace, A., E.M. Romney, and V.Z. Hale. 1973. Sodium relations in desert plants. I. Cation, contents of some species from the Mojave and Great Basin Deserts. Soil Sci. 115:284-287.

Wallace, A., E.M. Romney, and R.T. Mueller. 1982. Sodium relations in desert plants. 7. Effects of sodium chloride on Atriplex polycarpa and Atriplex canescens. Soil Sci. 134:65-68.

Watanabe, F.S., and S.S. Olsen. 1965. Test of an ascorbic acid method for determining phosphorus in water and $\mathrm{NaHCO}_{3}$ extracts from soils. Soil Sci. Amer. Proc. 29:677-678.

Welch, B.L. 1978. Relationships of soil salinity, ash and crude protein in Atriplex canescens. J. Range Manage. 31:132-133.

Welch, B.L., and S.B. Monsen. 1981. Winter crude protein among accessions of fourwing saltbush grown in a uniform garden. Great Basin Nat. 41:343-346. 